\title{
THERMALLY RESISTANT POLYMER COMPOSITES REINFORCED WITH FIBREGLASS
}

\section{Mihai GEORGESCU*, Maria SÖNMEZ, Mihaela NITUICĂ, Laura ALEXANDRESCU, Dana GURĂU}

\author{
INCDTP - Division: Leather and Footwear Research Institute, 93 Ion Minulescu, Bucharest, Romania, \\ mihai.georgescu@icpi.ro, mihai.georgesku@yahoo.com
}

Received: 29.05.2017

Accepted: 30.11 .2017

https://doi.org/10.24264/Ifj.17.4.7

\section{THERMALLY RESISTANT POLYMER COMPOSITES REINFORCED WITH FIBREGLASS}

ABSTRACT. The aim of this paper was to obtain and characterize polymeric composites based on polyamide (PA) and polycarbonate (PC), reinforced with chemically activated surface fibreglass (FG), with advanced properties and temperature resistance. Polyamide was employed as the polymeric matrix, and the polycarbonate as disperse phase. As PA and PC are immiscible due to the polarity differences, a polyoxazoline compatibiliser was used. Afterwards, fibreglass was introduced in this composite. However, in order to obtain these properties, many variations of recipes had to be tested, with different concentrations of the components. The starting point was a mixture of $70 \%$ PA and $30 \%$ PC. The amount of compatibiliser varied up to $5 \%$, and the FG amount, up to $30 \%$. The characteristics of these polymeric composites with compatibiliser and simple and treated fibreglass were studied.

KEY WORDS: polymeric composites, polyamide, polyethylene, fibreglass

\section{COMPOZITE POLIMERICE TERMOREZISTENTE RANFORSATE CU FIBRĂ DE STICLĂ}

REZUMAT. Scopul acestui articol a fost realizarea şi caracterizarea compozitelor polimerice pe bază de poliamidă (PA) şi policarbonat (PC), armate cu fibre de sticlă cu suprafeţe activate chimic (FG), cu caracteristici performante şi rezistente la temperatură. A fost utilizată ca matrice polimerică poliamida, iar faza dispersă a fost policarbonatul. PA şi PC fiind nemiscibile datorită diferenţelor de polaritate, a fost utilizat un compatibilizator pe bază de polioxazolină. În acest compozit s-au introdus, apoi, fibre de sticlă. Totuşi, în vederea obţinerii acestor proprietăţi au trebuit testate mai multe variante de reţete cu diferite concentraţii ale componenţilor. Astfel s-a pornit de la un amestec de $70 \%$ PA şi $30 \%$ PC. Cantitatea de compatibilizator a variat până la 5\%, iar cea de FG până la $30 \%$. Au fost studiate caracteristicile acestor compozite polimerice cu compatibilizator precum şi cu fibre de sticlă funcţionalizate şi nefuncţionalizate.

CUVINTE CHEIE: compozite polimerice, poliamidă, polietilenă, fibră de sticlă

\section{COMPOSITES POLYMÈRES THERMOSTABLES RENFORCÉS AUX FIBRES DE VERRE}

RÉSUMÉ. Le but de cet article était de concevoir et de caractériser des composites polymères à base de polyamide (PA) et polycarbonate (PC), renforcés aux fibres de verre activées chimiquement $(\mathrm{FG})$ avec des caractéristiques de haute performance et de résistance à la température. La polyamide a été utilisée comme matrice polymère et la phase dispersée était le polycarbonate. PA et PC étant non miscibles en raison des différences de polarité, un agent de compatibilité à base de polyoxazoline a été utilisé. La fibre de verre a ensuite été introduite dans ce composite. Cependant, afin d'obtenir ces propriétés, plusieurs variantes de recettes avec différentes concentrations des composants ont dû être testées. On a parti d'un mélange de $70 \%$ PA et $30 \%$ PC. La quantité d'agent de compatibilité a varié jusqu'à $5 \%$ et la quantité de fibres de verre jusqu'à $30 \%$. Les caractéristiques de ces composites polymères avec l'agent de compatibilité ainsi qu'aux fibres de verre fonctionnalisées et non-fonctionnalisées ont été étudiées.

MOTS CLÉS : composites polymères, polyamide, polyéthylène, fibre de verre

\footnotetext{
${ }^{*}$ Correspondence to: Mihai GEORGESCU, INCDTP - Division: Leather and Footwear Research Institute, 93 lon Minulescu, Bucharest, Romania, mihai.georgescu@icpi.ro, mihai.georgesku@yahoo.com
} 


\section{INTRODUCTION}

Composites can be defined as materials that consist of two or more chemically and physically different phases separated by a distinct interface. The different systems are combined judiciously to achieve a system with more useful structural or functional properties non-attainable by any of the constituents alone. Composites are becoming an essential part of today's materials due to the advantages such as low weight, corrosion resistance, high fatigue strength, and faster assembly. They are extensively used as materials in producing advanced structures [1, 2].

Composites are combinations of materials differing in composition, where the individual constituents retain their separate identities. These separate constituents act together to give the necessary mechanical strength or stiffness to the composite part. A composite is a material composed of two or more distinct phases (matrix phase and dispersed phase) and having bulk properties significantly different from those of any of the constituents. Matrix phase is the primary phase having a continuous character. Matrix is usually more ductile, a softer phase. It holds the dispersed phase and shares a load with it. Dispersed (reinforcing) phase is embedded in the matrix in a discontinuous form [1].

In this paper polymer blends based on polyamide (PA) and polycarbonate (PC) were obtained. PA is a widespread polymer in the industry with a low processing cost, and was mainly employed due to its high temperature resistance.

Polyamides have good dimensional stability, high rigidity (especially when PA is reinforced with fibreglass), good resistance to compression, wear, shocks and vibrations; they are hard materials, and maintain their hardness and tenacity at high temperatures, with no visible transformations up to $80-90^{\circ} \mathrm{C}$ [3-9]. PAs are semitransparent in moulded parts with thin wall and opaque in moulded parts with thick wall. Reinforcing polyamides results in improved properties of tensile strength, bending resistance and higher values for elastic modulus and hardness. Applications include mechanical engineering (friction parts, gears, wheel bands), automotive parts (housings, fans, parts with complex forms, fuel tanks, bushings, flexible cabling, brake fluid reservoirs), electrical and electronics parts, household items (fruit juicers, kitchen appliances, handles of tableware), sport and tourism equipment (ski boots, roller skates, tents, climbing ropes and cords, protective helmets, anti-drop system for bicycle chain) [10].

Due to the fibreglass strength it is possible to provide polymer composites with new properties. Fibreglass advantages include effective reinforcing, with minimal impact resistance loss, thermal stability and resistance, improved resistance.

Designing and development of multiphasic polymeric composites are strongly dependent on two major parameters: interface and morphology control. Generally, the term "morphology" refers to the shape and organization at a higher level than the atomic one (e.g. the arrangement of the elastomer molecules in the crystalline or amorphous regions) and how molecules are organized into more complex units. Thus, the morphology of polymeric composites indicates the size, shape and spatial distribution of the component phases. It is known that most of the mechanical, optical, rheological, physicalchemical and dielectric properties of polymer composites are strongly influenced by the type and finesse of phase structure.

PA and PC are immiscible due to differences in polarity, processing temperature and solubility. These factors lead to poor dispersion of PC in the PA matrix. It is necessary that the blend be compatibilised. The compatibilisation must accomplish: a) optimize interfacial tension, b) stabilize the morphology against high stress during forming, and c) enhance adhesion between the phases in the solid state $[11,12]$.

Grafted copolymers are used on a large scale as compatibilisation agents in blends with other plastic materials. These are, generally, obtained by grafting the free radicals in melt on the main chain. Most commonly used monomers are maleic anhydride, glycidyl methacrylate, vinyl and acrylic monomers and containing reactive functionalized groups. In this paper oxazoline (2-ethyl-2-oxazoline) was used as compatibiliser.

Polymer composites based on reinforced polymer blends are currently considered a new group of materials, required for highperformance applications. In this group of materials, required properties are obtained mainly by selecting the type of polymeric 
components, composition, adding fibreglass and processing conditions leading to optimal physical and mechanical properties.

In the last two decades a multitude of new multicomponent polymeric materials have been developed. Multiphase polymer polymeric composites have been identified as the most versatile method to produce new economic thermally resistant polymers that are able to meet the complex requirements of performance.

This paper was aimed at obtaining and characterization of polymeric composites with advanced features resistant to temperature, based on polyamide (PA) and polycarbonate (PC) reinforced with chemically activated surface fibreglass.

\section{MATERIALS AND METHODS}

\section{Materials}

Materials used were:

- Polyamide - standard PA for injection Sebamid 6 s3c (Basplast),

- Polycarbonate - CALIBRETM

polycarbonate resin, density $1.2 \mathrm{~g} / \mathrm{cm}^{3}$ (Trinseo Gmb),

- 2-ethyl-2-oxazoline - Mw-500.000, density: $1.14 \mathrm{~g} / \mathrm{cm}^{3} \quad$ (lit) (Sigma-Aldrich Chemistry, USA),

- Simple fibreglass - BMC3 $4.5 \mathrm{~mm}$,

- Organosilane - 3-Aminopropyl)

trimethoxysilane, Mw-179.29 g/mol, bp: $91-92^{\circ} \mathrm{C}$ (lit) (Sigma-Aldrich Chemistry, USA).

\section{Method}

Formulation of polymeric composites with resistance to high temperature, flame, and impact, a processing technology and formulations for these materials were designed. In order to make the comparison between composites possible, only the type and amount of fibreglass were varied. The ratio between the components of the polymeric composites is as follows: $70 \%$ PA, 30\% PC, 5\% compatibiliser and 10-30\% simple and treated fibreglass. In order to select the optimal variants, these new materials were characterized according to the rubber and plastic specific standards.

Table 1: Formulations of polymer composites based on PA/PC/FG

\begin{tabular}{lcccccc}
\hline Sample & UM & $P_{9}$ & $P_{10}$ & $P_{11}$ & $P_{12}$ & $P_{13}$ \\
\hline Polyamide & $\%$ & 70 & 70 & 70 & 70 & 70 \\
Polycarbonate & $\%$ & 30 & 30 & 30 & 30 & 30 \\
Oxazoline & $\%$ & 5 & 5 & 5 & 5 & 5 \\
Fibreglass & $\%$ & - & - & 10 & - & 30 \\
(APTMS) & & & & & & \\
Fibreglass & $\%$ & - & 10 & - & 30 & - \\
(simple) & & & & & & \\
\hline
\end{tabular}

The laboratory-scale technological process for polymeric composites reinforced with simple and treated (APTMS) fibreglass is detailed in Figure 1.

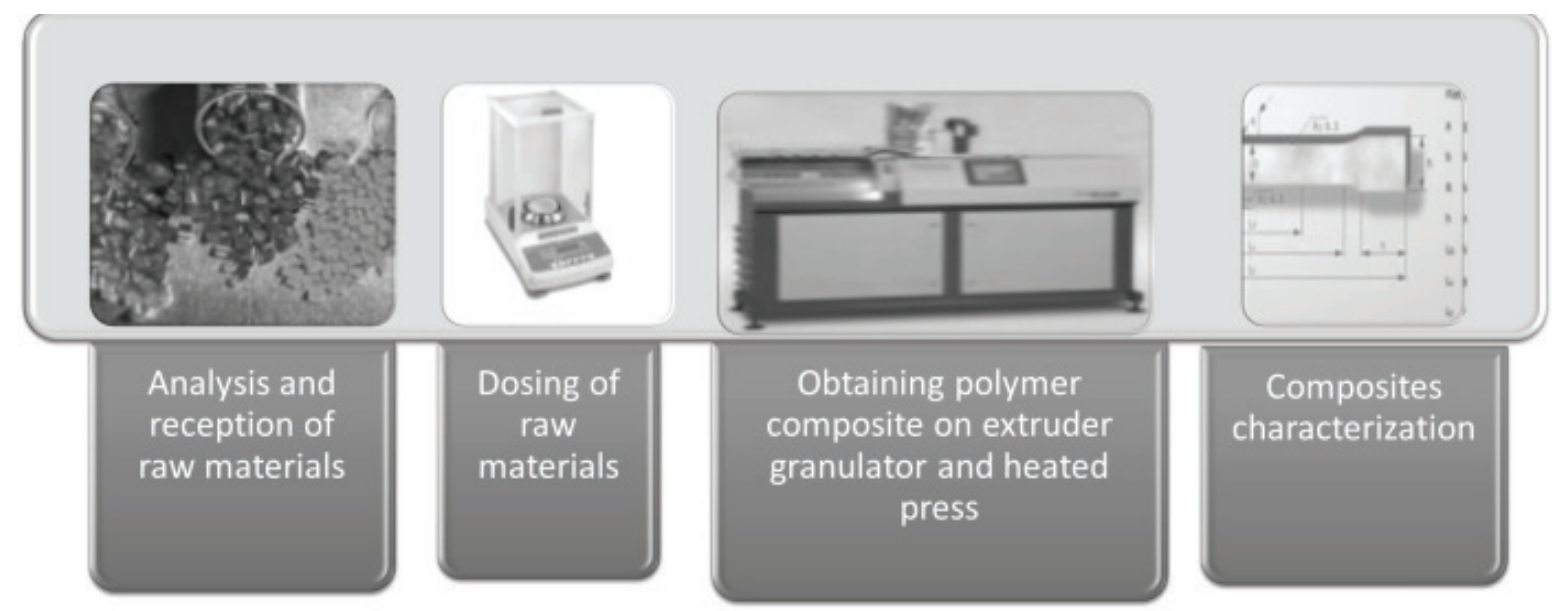

Figure 1. Stages for processing and characterization of the polymeric composites 
The formulations in Tables 1 were processed in a twin screw extruder. The method for achieving multiphase polymer composites is as follows:

- Weighing the raw materials, according to the formulations;

- Base components, PA and PC, along with the compatibiliser (oxazoline) are mixed together;

- Temperatures were set according to the Table 2;

- The previously obtained mix is introduced in the mixing chamber, and depending on the formulation, the fibreglass is added.

Processing parameters of the extrudergranulator are shown in Table 2 . They were set so as to obtain a homogeneous material, and the size of the composite granules was $3 \times 3 \mathrm{~mm}$.

Table 2: Processing parameters

\begin{tabular}{|c|c|c|c|}
\hline No. & Processing parameters & M.U. & Values \\
\hline \multirow{10}{*}{1} & Temperature in: & \multirow{10}{*}{${ }^{\circ} \mathrm{C}$} & \\
\hline & Zone I & & 180 \\
\hline & Zone II & & 190 \\
\hline & Zone III & & 200 \\
\hline & Zone IV & & 210 \\
\hline & Zone V & & 220 \\
\hline & Zone VI & & 220 \\
\hline & Zone VII & & 210 \\
\hline & Zone VIII & & 200 \\
\hline & Zone IX & & 200 \\
\hline 2 & $\begin{array}{c}\text { Extruder's twin-screws } \\
\text { speed (frequency converter) }\end{array}$ & $\mathrm{Hz}$ & 14 \\
\hline 3 & $\begin{array}{l}\text { Extruder's feeding screws } \\
\text { speed (frequency converter) }\end{array}$ & $\mathrm{Hz}$ & 5.3 \\
\hline 4 & Cutting wheel speed & RPM & 200 \\
\hline 5 & Running Current Intensity & A & 24 \\
\hline
\end{tabular}

\section{RESULTS AND DISCUSSION}

\section{Characterisation of Composites}

\section{Optical Microscopy Characterisation}

Functionalization plays an important role in the fibreglass final properties and implicitly on the polymeric composite embedding them, creating bonds with the polymeric materials used in the composite. Thus, the functioning of the glass fibers used in this paper was performed with 3-aminopropyltriethoxysilane $(5 \%)$ in ethyl alcohol medium.

To control the functioning of the glass fibers, they were observed microscopically. The microscope used for this purpose was the Leica CME Microscope, with magnification between 40X and 1000X and warm incident light. The images (Figure 2) show the deposition of the functional agent (APTMS) on the fibreglass.
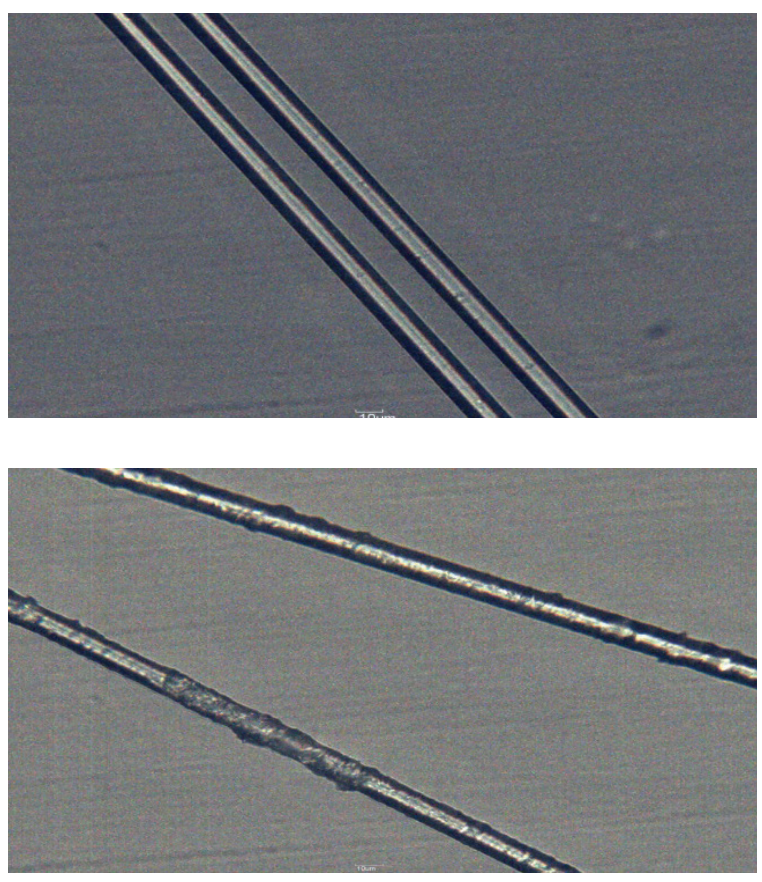

Figure 2. Microscopic images of simple and functionalized glass fibres (400X)

\section{Physical-Mechanical Characterisation}

The results of the physical-mechanical properties of the samples obtained for the polymer composites based on PA, compatibiliser, PC, and reinforced with fibreglass, are shown in Table 3.

Physical-mechanical characterization was carried out according to standards in force. Following the basic composites characterization, P9 sample (70\% PA / 30\% PC / 5\% compatibiliser), samples with simple and treated fibreglass (10$30 \%)$ were tested.

Table 3: Physical-mechanical characterization of the polymeric composites

\begin{tabular}{|c|c|c|c|c|c|}
\hline $\begin{array}{l}\text { Characteristic / } \\
\text { Sample }\end{array}$ & P9 & P10 & P11 & P12 & P13 \\
\hline $\begin{array}{l}\text { Hardness }{ }^{\circ} \text { Sh D } \\
\text { SR ISO 7619- } \\
\text { 1:2011 }\end{array}$ & 80 & 82 & 80 & 81 & 79 \\
\hline $\begin{array}{l}\text { Tensile strength, } \\
\mathrm{N} / \mathrm{mm}^{2} \text {, (SR } \\
\text { ISO } 37: 2012)\end{array}$ & 23.8 & 31.7 & 40 & 38.6 & 47 \\
\hline
\end{tabular}




\section{Hardness}

When adding simple fibreglass, hardness increases but using the treated fibreglass instead, the hardness decreases by $1-2^{\circ} \mathrm{Sh}$ D. Thus, for the polymeric composites containing compatibiliser and treated fibreglass this property decreases by $2-3^{\circ}$ Sh D.

\section{Tensile Strength}

Tensile strength decreases when mixing the plastomers, PA and PC, based on the ratio used between them. The addition of compatibiliser improves the tensile strength. With the addition of simple fibreglass tensile strength increases compared to P4 formulations. When using treated fibreglass with the compatibiliser, the value of tensile strength greatly improves. In that sense the composites $\mathrm{P} 11$ and $\mathrm{P} 13$ with $30 \%$ fibreglass show the best values of the tensile strength, of $40 \mathrm{~N} / \mathrm{mm}^{2}$ and $47 \mathrm{~N} / \mathrm{mm}^{2}$ respectively.

\section{Melt Flow Index}

The materials used have different characteristics and properties, such as colour, density, hardness, different processing temperature, etc. Thus, the melt flow index was determined at the same temperature, of $230^{\circ} \mathrm{C}$ and a pressure force of $5 \mathrm{Kg}$. The values of the melt flow index obtained for the polymeric composites processed in the Brabender mixer are shown in Figure 3.

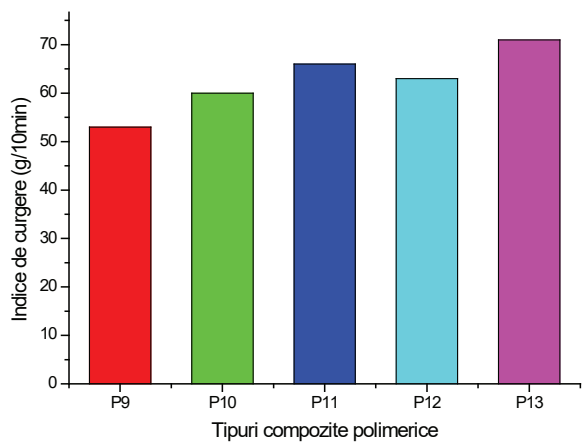

Figure 3. Melt flow index for polymeric composites

It is noted that there are considerable differences between the viscosities of the two base polymers (PA and PC) which affects the flow of material. Thus, the values obtained for PA were $60 \mathrm{~g} / 10 \mathrm{~min}$ and for $\mathrm{PC}, 11.7 \mathrm{~g} / 10 \mathrm{~min}$. Melt flow index for the obtained composite materials varies widely between these two extremes, due to the base polymer ratio, compatibiliser, and the type of fibreglass. The addition of the treated fibreglass in a proportion of $10 \%$ increases the melt index value from 53 to $60 \mathrm{~g} / 10 \mathrm{~min}$. When using 30\% APTMS functionalized fibreglass the melt index value increase to $71 \mathrm{~g} / 10 \mathrm{~min}$.

This characteristic is important in establishing the processing parameters of the polymeric composites into finished products, on the industrial equipment.

\section{CONCLUSIONS}

This paper presents new polyamide (PA) and polycarbonate (PC) thermally resistant polymers with high performance, reinforced glass fibres with chemically activated surfaces to meet the current quality requirements for the automotive industry.

After testing the composite samples the following were found:

- The compounds based on PA, PC thermoplastic polymers, compatibiliser and treated fibreglass have been selected because they will take advantage of the synergy of the two polymers such as chemical resistance, low water permeability, high temperature, flame, and impact resistance;

- The composite testing specimens were obtained in an electrical heated press, by means of compression, between its plates, at a temperature of $220^{\circ} \mathrm{C}$ and at a pressure of $300 \mathrm{kN}$;

- Developed formulations for polymer compounds based on $70 \%$ PA/ $5 \%$ compatibiliser/ $30 \%$ PC/ $10-30 \%$ simple and treated (APTMS) fibreglass;

- Hardness decreases when adding the compatibiliser, and for the polymeric composites containing compatibiliser and treated fibreglass this property decreases by $2-3^{\circ} \mathrm{Sh} D$.

- Tensile strength decreases when mixing the plastomers, PA and PC, based on the ratio used between them. The addition of compatibiliser improves the tensile strength of the composites. The composites P11 and P13 with 5\% compatibiliser and 
$30 \%$ treated fibreglass show the best values of the tensile strength, of $40 \mathrm{~N} / \mathrm{mm}^{2}$ and $47 \mathrm{~N} / \mathrm{mm}^{2}$, respectively.

- Melt flow index ranges vary widely for the obtained polymeric composites. Thus, the flow index of composites P9-P13 decreases with increasing percentage of PC. Using an amount of $5 \%$ of oxazoline compatibiliser the melt index value increases to $53 \mathrm{~g} / 10 \mathrm{~min}$. The addition of the treated fibreglass in a proportion of $10 \%$ the melt index value increases from 53 to $60 \mathrm{~g} / 10 \mathrm{~min}$. When using $30 \%$ APTMS functionalized fibreglass the melt index value increases to $71 \mathrm{~g} / 10 \mathrm{~min}$.

The data presented show that the fibreglass functionalized with APTMS favourably influences physical-mechanical and processing properties compared to the simple fibreglass.

\section{Acknowledgements}

This research was financed by ANCSI through NUCLEU Program 2016-2017, project codePN16340109:"NewTypes of Polycarbonate/ Polyamide/Fibreglass Compounds Resistant to Impact, Used in Automotive and Electrical Insulators Industries", contract no. 26N/2016.

\section{REFERENCES}

1. Jones, R.O., Ballone, P.A., A Combined Density Functional and Monte Carlo Study of Polycarbonate, Molecules, 2010, 15, 3680.

2. Kricheldorf, H., Luebbers, D., Polymers of CarbonicAcid. 3.ThermotropicPolycarbonates Derived from 4,4-dihydroxybiphenyl and Various Diphenols, Macromolecules, 1990, 23, 10, 2656-2662, https://doi.org/10.1021/ ma00212a010.

3. Liaw, D.J., Chang, P., Synthesis and Characterization of Aromatic and Brominated Aromatic Polycarbonates by Two-PhaseTransfer-Catalyzed Polycondensation of Bisphenols with Trichloromethyl Chloroformate, J Appl Polym Sci, 1997, 63, 195-204.

4. Liu, Z., Cunha, A.M., Yi, X.S., Bernardo, A.C., Key Properties to Understand the Performance of Polycarbonate Reprocessed by Injection Molding, J Appl Polym Sci, 2000, 77, 1393-1400.
5. Park, J.H., Hyun, J.C., Kim, W.N., Kim, S.R., Ryu, S.C., Extensional and Complex Viscosities of Linear and Branched Polycarbonates, Macromol Res, 2002, 10, 135-139.

6. Pokharkar, V., Sivaram, S., Poly(alkylene carbonate)s by the Carbonate Interchange Reaction of Aliphatic Diols with Dimethyl Carbonate: Synthesis and Characterization, Polymer, 1995, 36, 4851-4854, https://doi. org/10.1016/0032-3861(95)99302-B.

7. Lee, J., Song, C., Kim, J.I., Kim, J.H., Preparation of Aromatic Polycarbonates Nanoparticles Using Supercritical Carbon Dioxide, J Nanopart Res, 2002, 4, 53-59.

8. Sweileh, B.A., Al-Hiari, Y.M., Kailani, M.H., Mohammad, H.A., Synthesis and Characterization of Polycarbonates by Melt Phase Interchange Reactions of Alkylene and Arylene Diacetates with Alkylene and Arylene Diphenyl Dicarbonates, Molecules, 2010, 15, 5, 3661-3682, https://doi.org/10.3390/ molecules15053661.

9. Sathyanarayana, M.N., Yaseen, M., Role of Promoters in Improving Adhesion of Organic Coatings to a Substrate, Prog Org Coat, 1995, 26, 275-313, https://doi.org/10.1016/03009440(95)00572-2.

10. Loewenstein, K.L., The Manufacturing Technology of Continuous Glass Fibers, 3rd revised ed., Elsevier, 1993.

11. Drown, E.K., Moussawi, H.A., Drzal, L., Glass Fiber Sizings and Their Role in Fiber-Matrix Adhesion, Silanes and Other Coupling Agents, Ed. K.L. Mittal, VSP Utrecht, Netherlands, 513-529, 1992.

12. Sautrot, M., Abel, M.-L., Watts, J.F., Powell, J., Incorporation of an Adhesion Promoter in a Structural Adhesive: Aspects of Durability and Interface Chemistry, J Adhesion, 2005, 81, 2, 163-187, https://doi. org/10.1080/00218460590921995.

(C) 2017 by the author(s). Published by INCDTPICPI, Bucharest, RO. This is an open access article distributed under the terms and conditions of the Creative Commons Attribution license (http://creativecommons.org/licenses/by 